\title{
Effects of rice varieties (Oryza sativa L.) on the quality of sponge cake
}

\author{
Hee Nam Jung* \\ Department of Food and Cooking Science, Suncheon National University, Suncheon 57922, Korea
}

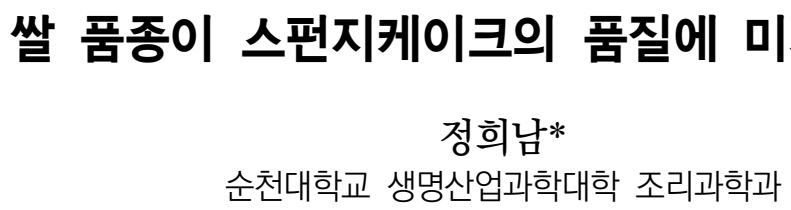

\begin{abstract}
This study aimed to compare the physicochemical properties of four rice varieties ('Suwon 541', 'Suwon 542', 'Ilmi', 'Goami') and their effect on the quality of sponge cake. The amylose contents in 'Suwon 541', 'Suwon 542', 'Ilmi', and 'Goami' were $19.69 \%, 18.15 \%, 18.62 \%$, and $26.92 \%$, respectively. The average particle size of 'Suwon 542' $(21.87 \mu \mathrm{m})$ was significantly lower than that of the other varieties. The water absorption index (WAI) was highest for 'Goami' and the water solubility index (WSI) was highest for 'Suwon 541'. The amylogram results indicated that initial pasting temperature was the highest for 'Suwon 541', where as the setback was the highest for 'Goami' and the lowest for 'Ilmi'. 'Suwon 541' flour exhibited low volume and high cake hardness because of its high initial pasting temperature. Sponge cakes prepared with 'Suwon 542', which exhibited fine grain size and low WAI and WSI, had low hardness owing the low specific gravity of the batter and high cake volume. The low-setback 'Ilmi' flour was expected to have a retarding retrogradation effect on cakes. Sponge cakes prepared with 'Goami' flour possessed good characteristics although its high setback was expected to degrade the texture due to rapid retrogradation. The overall acceptability was the highest for 'Suwon 542' and 'Ilmi'. Thus, 'Suwon 542' and 'Ilmi' were found to have a more positive effect on the quality of sponge cakes compared with the other varieties.
\end{abstract}

Key words : rice variety, amylogram property, sponge cake, quality characteristic, texture

서 론

최근 1 인 가구 증가 및 식생활의 간편화를 추구하는 인구 가 증가함에 따라 밥 대신 빵류로 식사를 대체하는 생활패턴 으로 변화하고 있어 주식용 쌀의 소비는 계속 감소하는 추세 이다(Han, 2011). 빵, 국수 등의 주원료인 밀가루는 국내 자 급률이 낮고 대부분 수입에 의존하고 있으며, 수입밀의 대부 분이 post harvest를 통해 유입되고 있다(Heo과 Lee, 2005). 또한, 밀에 함유된 gluten은 장벽의 융모를 수축시키고 소화
흡수를 저해하며, 장 면역질환을 일으키는 요인으로 알려져 있어 gluten 무첨가 제품 개발의 필요성이 대두되고 있다 (Kim과 Chung, 2018).

글루텐은 빵반죽에서 점탄성을 부여하고 구조를 형성하는 데 기여하는 단백질로, 밀의 gliadins, 보리의 hordeins, 호밀 의 secalins, 귀리의 avenins 등의 프롤라민류를 포괄하여 불 린다(Capriles와 Areas, 2014; Wronkowska 등, 2013). 글루 텐이 없는 곡물은 메밀, 옥수수, 퀴노아, 쌀 및 기장이 포함되 며, 우리나라와 같이 밀에 비해 쌀의 식량자급률이 월등히 높

*Corresponding author. E-mail : hnjung@scnu.ac.kr, Phone : +82-61-750-3690, Fax : +82-61-750-3690

Received 07 May 2020; Revised 13 May 2020; Accepted 18 May 2020.

Copyright (c) The Korean Society of Food Preservation.

This is an Open Access article distributed under the terms of the Creative Commons Attribution Non-Commercial License (http://creativecommons.org/licenses/by-nc/4.0) which permits unrestricted non-commercial use, distribution, and reproduction in any medium, provided the original work is properly cited. 
은 나라에서 쌀가루는 gluten 무첨가 식품의 제조에 유용한 대안이 될 수 있다. 밀가루를 쌀가루로 대체하기 위하여 쌀가 루에 대한 효소처리(Kim 등, 2011; Kim 등, 2013), 수분열처 리(Lee와 Shin, 2006; Seo와 Kim, 2011), 제분방법(Kim과 Chung, 2018; Oh 등, 2018; Park 등, 2017) 등을 통하여 가공 적성을 향상시키는 여러 연구들이 보고되었다. 건식제분은 공정이 간단하고 처리시간이 짧으나 전분의 손상도가 높아 가 공적성이 떨어지고, 습식제분은 손상도가 낮아 2 차 가공에는 유리하나 영양손실과 가공비용이 비싼 단점이 있다(Chiang와 Yeh, 2002; Choi 등, 2005). 이러한 문제점을 보완하기 위하 여 건식제분에 적합한 설갱(Oh 등, 2011), 한가루(Kim 등, 2017) 품종의 가공적성 연구가 보고된 바 있다. 건강지향적 인 식생활을 위하여 gluten이 함유된 밀가루 제품의 단점을 보완하고, 국내 쌀 소비를 촉진하기 위하여 가공식품에 적합 한 쌀 품종의 개발과 더불어 이를 이용한 다양한 쌀가공 제품 의 개발은 앞으로 지속적으로 연구되어야 할 과제이다.

스펀지케이크는 식사대용과 간식용으로 세계적으로 널리 소비되고 있는 베이커리 제품이다. 케이크의 품질은 반죽의 공기흡입, 반죽의 안정성 및 열경화 단계에 의해 결정된다 (Krupa-Kozak 등, 2019). 밀가루에 함유된 글루텐은 베이커리 제품의 외관, 질감, 기호도 및 전반적인 품질에 중요한 역할을 하는데, 케이크는 빵과는 달리 높은 설탕과 지방 함량으로 인 해 강한 글루텐 네트워크가 형성되지 않는다(Majzoobi 등, 2016). 쌀가루는 글루텐을 함유하지 않아 발효에 의해 생성된 이산화탄소를 망상구조 안에 보유할 수 없어 빵보다는 케이크 와 과자류의 제조에 더 용이하다(Kim과 Chung, 2018). 쌀가루 를 이용하여 빵을 제조할 경우, 쌀가루의 밀가루 대체효과는 제한적이나(Gujral 등, 2003), 달걀의 기포성을 이용한 케이크 류는 밀가루의 글루텐에 의한 점탄성에 영향을 크게 받지 않기 때문에 밀가루의 전부를 쌀가루로 대체할 수 있다(Lee 와 Hwang, 2016). 이와 관련하여 호박(Lee, 2010), 돼지감자 (Kim 등, 2014), 녹차(Lee와 Hwang, 2016)와 같은 기능성 식 재료를 첨가한 쌀 스펀지케이크에 관한 연구가 보고되었으나, 쌀케이크의 제조에 적합한 쌀 품종에 관한 연구는 전무하다.

쌀가루는 품종에 따라 각각 다른 이화학적 특성을 가진다. 쌀의 아밀로오스 함량은 제과, 제빵, 제면 과정에서 반죽과 최종제품의 품질에 영향을 미치는 중요한 요인으로 알려져 있으나, 아밀로오스 함량만으로 최종제품의 품질을 예측하기 는 충분하지 않다. 가공적성은 가용성 전분의 비율, 호화점 성, 제분특성 등 다양한 요인에 의해 영향을 받으며, 최종제 품에 따라 종합적으로 해석할 필요가 있다(Kang 등, 2016). 현재 국내에서는 재배기술의 발전과 가공식품의 다양화로 취 반, 양조, 국수, 발아현미, 무균포장밥, 제분 등 다양한 용도의 가공용 쌀 품종이 꾸준히 개발되고 있으나, 그 중 일부 품종들
이 재배면적의 대부분을 차지하고 있으며(Kim, 2011), 취반과 양조용도를 제외하고는 산업화되지 못하고 있는 실정이다.

따라서 본 연구에서는 현미밥 전용 품종인 수원 541 , 건식 제분용 쌀품종인 수원 542호, 밥쌀용 고품질쌀 일미, 고아밀 로스 품종인 고아미 등 국내에서 생산되고 있는 4 품종 쌀가 루의 이화학적 특성을 비교하였고, 이를 이용하여 스펀지케 이크를 제조한 후 품질 특성을 조사하였다. 이를 통하여 스펀 지케이크의 제조에 적합한 쌀품종을 확인하고, 쌀가공산업에 유용한 기초자료를 제공하고자 하였다.

\section{재료 및 방법}

\section{실험재료}

본 실험에서 사용된 쌀품종은 2016년에 생산된 수원 541, 수원 542, 일미, 고아미 품종을 전남농업기술원(Naju, Korea) 으로부터 제공받아 백미로 도정한 후 초미립분쇄기(특허 0591778, Duksan Co., Siheung, Korea)로 제분하여 실험에 사용하였다.

\section{쌀가루의 이화학적 특성 분석}

쌀가루의 아밀로오스 함량은 비색법(Williams 등, 1970)을 이용하여 측정하였다. 입도분석은 particle size analyzer (ELSZ-2000, Otsuka Electronics, Osaka, Japan)를 이용하여 측정하였다. 입자크기 분포는 $10 \%\left(D_{10}\right), 50 \%\left(D_{50}\right), 90 \%\left(D_{90}\right)$ 의 누적 부피 백분율에서의 입자 직경을 나타내었고, 이들 값 을 이용하여 평균입자크기인 $D_{50}$ 과 분산 $\left(\left(D_{90}-D_{10}\right) / D_{50}\right)$ 으로 나타내었다. 색도 측정은 표준백색판(L: $91.64, \mathrm{a}: 0.55, \mathrm{~b}$ : 2.42)으로 보정된 색차계(JC 801S, Color Techno System Co., Tokyo, Japan)를 사용하여 Hunter's value L(lightness), $\mathrm{a}$ (redness), b(yellowness) 값을 측정하였다. 쌀가루의 수분흡 수지수(water absorption index, WAI)는 쌀가루 $3 \mathrm{~g}$ 과 증류수 $30 \mathrm{~mL}$ 를 원심분리관에 넣고 30 분간 진탕 교반한 후, 원심분 리기(MF 600R, Hanil Electric Co., Seoul, Korea)를 이용하 여 $3,000 \mathrm{rpm}$ 에서 30 분간 원심분리 하였다. 상등액을 제외한 침전물의 무게를 평량하여 시료 $\mathrm{g}$ 당 흡수된 수분함량을 WAI 로 계산하였다. 수분용해지수(water solubility index, WSI)는 $\mathrm{WAI}$ 측정 시 회수한 상등액을 증발접시에 옮긴 후, $105^{\circ} \mathrm{C}$ 의 dry oven(HB-502L, Hanbaek Co., Bucheon, Korea)에서 건 조시켜 얻어진 고형분의 무게를 시료에 대한 백분율(\%)로 나 타내었다.

\section{쌀가루의 아밀로그램 호화특성 측정}

쌀가루의 호화특성은 Micro Visco-Amylograph(Brabender Measurement \& Control System, Duisburg, Germany)를 사 
용하여 측정하였다(AACC, 2000). 쌀가루 현탁액은 쌀가루 $10 \mathrm{~g}$ 과 증류수 $90 \mathrm{~mL}$ 를 $100 \mathrm{~mL}$ 의 용기에 넣어 혼합한 다음, $30^{\circ} \mathrm{C}$ 에서 10 분간 교반한 후, 가열속도 $5.0^{\circ} \mathrm{C} / \mathrm{min}$, 회전속도 $250 \mathrm{rpm}$ 조건으로 $95^{\circ} \mathrm{C}$ 까지 가열하고, 15 분간 유지한 후 $5.0^{\circ} \mathrm{C} / \mathrm{min}$ 속도로 $50^{\circ} \mathrm{C}$ 까지 냉각하였다. 측정된 amylograph 로부터 initial pasting temperature, peak viscosity, trough viscosity, cold viscosity, breakdown, setback값을 얻었다.

\section{스펀지케이크의 제조}

스펀지케이크는 4품종의 쌀가루를 이용하여 제조되었다. 달걀은 난백과 난황으로 분리하여 난백 $190 \mathrm{~g}$ 에는 설탕 70 $\mathrm{g}$ 과 물엿 $10 \mathrm{~g}$, 난황 $90 \mathrm{~g}$ 에는 설탕 $60 \mathrm{~g}$ 을 혼합하여 반죽기 (5KPM5E, Whirlpool Inc., Benton Harbor, MI, USA)에서 각각 교반하였고, 난백은 기포를 형성시켰다. 교반한 난황에 기포가 형성된 난백 3 분의 1 을 넣고 잘 섞은 다음, 쌀가루 $100 \mathrm{~g}$, 소금 $1 \mathrm{~g}$, 베이킹파우더 $1 \mathrm{~g}$ 을 첨가하여 잘 혼합하였 다. 대두유 $50 \mathrm{~g}$ 과 물 $20 \mathrm{~g}$ 을 순서대로 잘 섞어 준 다음, 남아 있는 난백을 모두 넣고 잘 혼합하여 반죽을 완성하였다. 완성 된 반죽은 $8 \mathrm{inch}$ 의 원형 팬에 $350 \mathrm{~g}$ 을 팬닝하여 $180^{\circ} \mathrm{C}$ 로 예 열된 전기오븐(CPC-102, Dae Yung machinary Co., Seoul, Korea)에서 25분간 구웠다. 완성된 스펀지케이크는 실온에서 1 시간 동안 방냉한 후 실험에 사용하였다.

\section{스펀지케이크 반죽의 비중 측정}

스펀지케이크 반죽의 비중은 AACC method 10-15(2000)에 따라 측정하였다. 비중컵에 담은 반죽의 무게에 대한 물의 무 게의 비 $(\mathrm{g} / \mathrm{g})$ 로 나타내었다.

\section{스펀지케이크의 비용적 측정}

스펀지케이크의 비용적은 스펀지케이크의 무게와 부피 에 의해 계산되었다. 부피는 AACC method 10-05(2000)에 따라 측정하였고, 비용적은 중량에 대한 부피의 비 $(\mathrm{mL} / \mathrm{g})$ 로 표시하였다.

\section{스펀지케이크의 단면 및 기공모양 관찰}

스펀지케이크의 단면은 디지털카메라(Nikon, Tokyo, Japan), 내부의 기공형태는 비디오현미경(SV-32, Sometech Co., Seoul, Korea)을 이용하여 관찰하였다.

\section{스펀지케이크의 색도 측정}

스펀지케이크 crumb의 색도는 표준백색판(L: 92.41 , a: 0.69, b: 3.18)으로 보정된 색차계(Color Techno System Co.) 를 사용하여 Hunter's value $\mathrm{L}, \mathrm{a}, \mathrm{b}$ 값을 측정하였다.

\section{스펀지케이크의 물성 측정}

스펀지케이크의 물성은 texture analyzer(TA-XT2i, Stable Micro System Co., Surrey, UK)를 이용하여 texture profile analysis(TPA)로 분석하였고, crumb 부분을 $20 \times 20 \times 20 \mathrm{~mm}$ 의 크기로 잘라 측정하였다. 측정 조건은 test speed: 1.0 $\mathrm{mm} / \mathrm{s}$, strain: $50 \%$, probe: $45 \mathrm{~mm}$ cylinder로 하였고, 측정 후 얻어진 force-distance curve로부터 hardness, springiness, cohesiveness 및 chewiness를 구하였다.

\section{스펀지케이크의 관능검사}

쌀 품종에 따른 스펀지케이크의 기호도를 측정하기 위하 여 총 34명의 건강한 일반인을 대상으로 하였고, 여자 18 명, 남자 16 명이었으며, 20 대 17 명, 30대 8명, 40 대 이상 9명이 패널로 참여하였다. 관능검사의 실시는 한 개의 시료를 먹고 나면 반드시 물로 입안을 헹구도록 하였고, 1-2분 지난 후에 다른 시료를 평가하도록 하였다. 제시된 시료의 크기는 $30 \times 30 \times 30 \mathrm{~mm}$ 이었고, 평가 항목은 color, flavor, taste, texture 및 overall acceptability이며, 각각의 특성은 7점 척도 로 평가하였다(1점은 '매우 좋지 않다', 7점은 '매우 좋다'). 관능검사는 순천대학교 생명윤리심의위원회의에서 승인을 받은 후 시행되었다(Approval number: 1040173-201902HR-007-02).

\section{통계처리}

본 연구의 결과는 SPSS 20.0(IBM, Armonk, NY, USA)를 이용하여 분석하였으며, 평균, 표준편차, 일원배치분산분석 및 Duncan의 다중범위 검정을 실시하여 쌀 품종간의 유의적 인 차이를 검증하였다 $(\mathrm{p}<0.05)$.

\section{결과 및 고찰}

\section{쌀가루의 이화학적 특성}

쌀가루의 아밀로오스 함량, 입도 분석, 색도, 수분흡수지수 (WAI) 및 수분용해지수(WSI)를 측정한 결과는 Table 1과 같 다. 아밀로오스 함량은 고아미에서 $26.92 \%$ 로 가장 높았고, 나머지 품종들은 $18.15-19.69 \%$ 범위였다. 평균입자 크기인 $D_{50}$ 은 수원 542에서 $21.87 \mu \mathrm{m}$ 로 다른 품종에 비해 제분 시 더 고운 입자를 갖는 것으로 측정되었고, 쌀가루 입자의 분포 정도를 나타내는 분산값은 일미에서 21.87로 24.43-25.50의 분산값을 갖는 다른 품종들에 비해 낮게 나타나 입자 분포가 더 균일한 것으로 나타났다. 백색도는 96.44-97.20으로 고아 미에서 가장 높았다. a값은 0.12-0.61, b값은 4.45-6.40으로 수원 542에서 가장 높았다. WAI는 고아미에서 1.71 로 가장 높았고, 그다음은 수원 541, 일미 및 수원 542 순이었으며, 
Table 1. Physicochemical properties of rice flours

\begin{tabular}{|c|c|c|c|c|}
\hline Sample & 'Suwon 541' & 'Suwon 542' & 'Ilmi' & 'Goami' \\
\hline Amylose content $(\%)$ & $19.69 \pm 1.29^{1) \mathrm{b} 2)}$ & $18.15 \pm 0.88^{b}$ & $18.62 \pm 0.84^{\mathrm{b}}$ & $26.92 \pm 1.54^{\mathrm{a}}$ \\
\hline$D_{50}(\mu \mathrm{m})$ & $24.43 \pm 0.42^{\mathrm{a}}$ & $21.87 \pm 0.55^{\mathrm{b}}$ & $25.50 \pm 0.75^{\mathrm{a}}$ & $25.03 \pm 0.81^{\mathrm{a}}$ \\
\hline Dispersion $\left(\left(D_{90}-D_{10}\right) / D_{50}\right)^{3)}$ & $2.35 \pm 0.09^{\mathrm{bc}}$ & $2.48 \pm 0.07^{\mathrm{ab}}$ & $2.25 \pm 0.04^{\mathrm{c}}$ & $2.52 \pm 0.08^{\mathrm{a}}$ \\
\hline $\mathrm{L}$ & $96.44 \pm 0.03^{\mathrm{d}}$ & $96.57 \pm 0.04^{\mathrm{c}}$ & $97.07 \pm 0.04^{\mathrm{b}}$ & $97.20 \pm 0.04^{\mathrm{a}}$ \\
\hline a & $0.39 \pm 0.03^{\mathrm{c}}$ & $0.61 \pm 0.03^{\mathrm{a}}$ & $0.55 \pm 0.03^{\mathrm{b}}$ & $0.12 \pm 0.04^{\mathrm{d}}$ \\
\hline $\mathrm{b}$ & $5.59 \pm 0.08^{\mathrm{c}}$ & $6.40 \pm 0.11^{\mathrm{a}}$ & $5.90 \pm 0.07^{\mathrm{b}}$ & $4.45 \pm 0.07^{\mathrm{d}}$ \\
\hline WAI $(\mathrm{g} / \mathrm{g})$ & $1.55 \pm 0.03^{\mathrm{c}}$ & $1.20 \pm 0.01^{\mathrm{d}}$ & $1.59 \pm 0.04^{\mathrm{b}}$ & $1.71 \pm 0.01^{\mathrm{a}}$ \\
\hline WSI (\%) & $2.57 \pm 0.08^{\mathrm{a}}$ & $1.78 \pm 0.15^{\mathrm{b}}$ & $2.41 \pm 0.15^{\mathrm{a}}$ & $1.91 \pm 0.19^{\mathrm{b}}$ \\
\hline
\end{tabular}

${ }^{1)} \mathrm{Mean} \pm \mathrm{SD}(\mathrm{n}=3-10)$.

${ }^{2) a-d}$ Means with different superscript are significantly different by Duncan's multiple test $(\mathrm{p}<0.05)$.

${ }^{3)} D_{10}$, particle size of the minimum $10 \%$ measurement; $D_{50}$, particle size of the minimum $50 \%$ measurement; $D_{90}$, particle size of the minimum $90 \%$ measurement.

아밀로오스 함량이 높을수록 높은 경향을 보였다. Sompong 등(2011)은 아밀로오스 함량은 WAI와 최종점도에 정의 영 향을 미친다고 보고하여 본 연구와 일치하였다. WAI는 아밀 로오스 함량 이외에 전분의 손상정도, 입자크기 및 제분방법 에 의해서도 영향을 받을 수 있다(Kang 등, 2016; Oh 등, 2018; Park 등, 2017; Sompong 등, 2011). WSI는 수원 541 과 일미에서 각각 $2.57,2.41$ 로 높았고, 고아미와 수원 542에 서 각각 $1.91,1.78$ 로 유의적으로 낮았다. Wadchararat 등 (2006)은 WSI와 아밀로오스 함량 간의 반비례 관계를 보고 하였으나, Table 1의 결과에서 WSI는 아밀로오스 함량과 뚜 렷한 관계를 보이지 않았다. 이러한 결과는 WSI는 아밀로오 스 함량 이외에도 입자크기, 단백질 및 손상전분 등이 복합적 으로 영향을 미쳤기 때문으로 생각된다(Abebe 등, 2015; Chaiwanichsiri 등, 2012).

\section{아밀로그램 호화특성}

품종별 쌀가루의 아밀로그램 호화특성을 측정한 결과는 Table 2와 같다. 호화개시온도는 $64.02-66.42^{\circ} \mathrm{C}$ 이었고, 수원 541 에서 $66.42^{\circ} \mathrm{C}$ 로 유의적으로 높았다. 쌀가루의 높은 호화 온도는 굽기 과정 중 구조형성 지연과 최종제품의 부피감소 등 내부구조에 부정적인 요인으로 작용한다고 하였다(Yoon 등, 2011). 최고점도는 일미에서 $742.40 \mathrm{BU}$ 로 가장 높았고, 고아미에서 $392.40 \mathrm{BU}$ 로 가장 낮았다. 아밀로펙틴의 가지사 슬 분포 차이는 호화 온도에 영향을 미치며, 아밀로오스 함량 이 높으면 팽윤이 억제되어 호화 시 점도가 낮게 나타나는 것으로 보고되었다(Lee 등, 2017). 또한, 최고점도는 전분입 자의 팽윤 정도와 팽윤된 전분입자간의 상호작용, 가열 중 전 분입자로부터 용출된 가용성 전분의 존재 등에 영향을 받는 것으로 알려져 있다(Huh 등, 2016). 최저점도는 304.80$370.00 \mathrm{BU}$ 이었고, 일미에서 유의적으로 높았다. 냉각점도는 고아미에서 $792.40 \mathrm{BU}$ 로 일미, 수원 541 및 수원 542에 비 해 유의적으로 높게 나타나 고아밀로오스 품종이 냉각 시 아

Table 2. Amylogram properties of rice flours

\begin{tabular}{lcccc}
\hline \multicolumn{1}{c}{ Sample } & 'Suwon 541' & 'Suwon 542' & 'Ilmi' & 'Goami' \\
\hline Initial pasting temp. $\left({ }^{\circ} \mathrm{C}\right)$ & $66.42 \pm 0.70^{1) \mathrm{a} 2)}$ & $65.14 \pm 0.21^{\mathrm{b}}$ & $64.76 \pm 0.34^{\mathrm{bc}}$ & $64.02 \pm 1.18^{\mathrm{c}}$ \\
Peak (BU) & $677.00 \pm 15.46^{\mathrm{b}}$ & $651.00 \pm 14.40^{\mathrm{c}}$ & $742.40 \pm 12.22^{\mathrm{a}}$ & $392.40 \pm 12.01^{\mathrm{d}}$ \\
Trough (BU) & $335.80 \pm 6.30^{\mathrm{b}}$ & $327.20 \pm 3.03^{\mathrm{b}}$ & $370.00 \pm 10.27^{\mathrm{a}}$ & $304.80 \pm 9.81^{\mathrm{c}}$ \\
Cold (BU) & $666.80 \pm 21.05^{\mathrm{b}}$ & $660.20 \pm 15.55^{\mathrm{b}}$ & $660.00 \pm 17.28^{\mathrm{b}}$ & $792.40 \pm 27.17^{\mathrm{a}}$ \\
Breakdown (BU) & $341.00 \pm 10.22^{\mathrm{b}}$ & $323.80 \pm 15.48^{\mathrm{c}}$ & $372.00 \pm 11.00^{\mathrm{a}}$ & $87.60 \pm 9.40^{\mathrm{d}}$ \\
Setback (BU) & $328.60 \pm 21.34^{\mathrm{b}}$ & $330.40 \pm 17.21^{\mathrm{b}}$ & $288.00 \pm 14.02^{\mathrm{c}}$ & $482.80 \pm 16.96^{\mathrm{a}}$ \\
\hline
\end{tabular}

${ }^{1)}$ Mean \pm SD $(\mathrm{n}=5)$

${ }^{2) a-d}$ Means with different superscript are significantly different by Duncan's multiple test $(p<0.05)$. 
밀로오스 분자의 재결정화에 의해 더 높은 점도를 보였다. 호화액의 안정도를 나타내는 지표인 breakdown은 일미에 서 $372.00 \mathrm{BU}$ 로 가장 높았고, 고아미에서 $87.60 \mathrm{BU}$ 로 가장 낮게 나타나 품종간에 차이를 보였다. Setback은 전분입자의 재배열에 의한 전분의 노화 정도를 나타내며, 값이 클수록 노 화속도가 빠름을 의미한다(Kringel 등, 2017). Setback은 고 아미에서 $482.80 \mathrm{BU}$ 로 가장 높았고, 수원 542, 수원 541에서 각각 $330.40,328.60 \mathrm{BU}$ 이었고, 일미에서 288.00 BU로 가장 낮았다. 아밀로그램 호화특성을 분석한 결과, 고아밀로스 품 종인 고아미에 비해 일미, 수원 541 및 수원 542에서 호화개 시온도, 최저점도 및 breakdown은 높았고, setback은 낮았다. 케이크의 노화와 관련하여 setback이 높은 고아미는 저장기간 이 길어질수록 질감에 대한 품질이 저하될 수 있으며, Yoon 등(2011)도 고아밀로오스 품종인 고아미와 고아미 3 호의 setback이 높게 나타나 다른 품종에 비해 전분의 결정화가 빠 르게 일어날 것을 예측하였다. 반면에 주로 취반용도로만 이 용되고 있는 일미 품종의 낮은 setback 값은 저장 중 케이크 의 질감에 긍정적인 영향을 줄 수 있을 것으로 생각된다.

\section{스펀지케이크의 품질 특성}

반죽의 비중, 케이크의 비용적 및 색도를 측정한 결과는 Table 3 과 같다. 반죽의 비중은 수원 541 , 일미, 고아미에서 0.47-0.48이었고, 수원 542에서는 0.45 로 유의적으로 낮았 다. 반죽의 비중은 반죽 내에 포집된 공기의 비율을 나타내며, 일반적으로 반죽의 비중이 높으면 반죽의 기포 함유량이 적기 때문에 완제품의 부피는 감소한다고 보고되었다(Krupa-Kozak 등, 2019; Majzoobi 등, 2014). 스펀지케이크의 비용적은 수 원 542에서 가장 높았고, 수원 541에서 가장 낮게 나타나 높 이와 비용적은 같은 경향을 보였다. 케이크의 부피는 반죽의 점도와 반죽 매트릭스 내부의 기공의 분포와 유지에 의존하 므로 반죽 내의 공기의 분포가 아니라 굽기 중 공기층을 유지 하는 능력이 필요하다(Edoura-Gaena 등, 2007). 밀제품의 경 우, 밀의 gluten이 반죽을 구울 때 탄산가스, 공기, 수분에서
생긴 증기를 보유하면서 팽창하기 때문에 케이크의 부피가 증가하게 되며, 반죽의 비중이 낮을수록 대체적으로 큰 부피 의 케이크를 얻게 된다(An 등, 2016). 그러나 본 연구에서는 수원 541, 일미, 고아미 간에 반죽의 비중은 유사하였으나, 케이크의 비용적은 일미와 고아미에 비해 수원 541에서 유의 적으로 낮게 나타나 세 품종 간에 차이를 보였다. 이는 쌀가 루의 호화특성 결과(Table 2)에서 수원 541호의 높은 호화개 시온도가 굽기 중 구조형성을 지연시킨 것으로 생각된다.

스펀지케이크의 L값은 수원 542와 고아미에서 각각 77.83 및 77.81로 높았고, 수원 541과 일미에서 각각 77.26 및 77.05로 유의적으로 낮게 나타났다. a값은 일미와 수원 541 에서 각각 0.37 및 0.35 로 높았고, 수원 542 에서 -0.26 으로 유의적으로 낮았다. b값은 수원 541에서 28.86으로 가장 높 았고, 수원 542에서 27.35로 가장 낮았으며, 시료 간에 유의 한 차이를 보였다. 색도 측정 결과, 수원 542와 고아미에서 $\mathrm{L}$ 값은 높고 $\mathrm{a}$ 값과 $\mathrm{b}$ 값은 낮게 나타나 수원 541과 일미에 비 해 crumb 색이 더 밝은 경향을 보였다. 케이크의 색은 재료 의 종류, 첨가량 및 부피에 의해 영향을 받는다.

스펀지케이크의 단면과 내부 구조는 Fig. 1과 같다. 단면 (up)은 쌀품종에 따른 스펀지케이크의 높이 및 부피의 차이 를 보여준다. 내부 구조(down)는 수원 541을 제외한 나머지 품종의 스펀지케이크에서 균일한 기공을 관찰할 수 있었다. 수원 541은 다른 시료에 비해 케이크의 높이가 낮고 기공의 분포가 일정하지 않은 것으로 관찰되었다. 이는 수원 541의 기공 유지력이 낮은 결과로 굽기 과정 중 기공이 깨지면서 기공들끼리 합쳐지는 동시에 붕괴되는 현상에서 비롯된 것으 로 생각된다.

\section{스펀지케이크의 물성}

케이크 crumb의 물성을 측정한 결과는 Table 4 와 같다. 탄 력성과 응집성은 쌀품종 간에 차이가 없었으나, 경도와 씹힘 성은 수원 541에서 높았고, 수원 542에서 유의적으로 낮았 다. 이러한 결과는 수원 542 를 이용한 스펀지케이크의 높이

Table 3. Physical properties of sponge cake prepared with different rice flours

\begin{tabular}{|c|c|c|c|c|}
\hline Sample & 'Suwon 541 ' & 'Suwon 542' & 'Ilmi’ & ‘Goami’ \\
\hline Specific gravity of batter & $0.48 \pm 0.01^{1) \mathrm{a} 2)}$ & $0.45 \pm 0.02^{\mathrm{b}}$ & $0.47 \pm 0.00^{\mathrm{a}}$ & $0.48 \pm 0.01^{\mathrm{a}}$ \\
\hline Specific volume $(\mathrm{mL} / \mathrm{g})$ & $1.96 \pm 0.05^{\mathrm{d}}$ & $2.55 \pm 0.05^{\mathrm{a}}$ & $2.14 \pm 0.04^{b}$ & $2.06 \pm 0.04^{\mathrm{c}}$ \\
\hline $\mathrm{L}$ & $77.26 \pm 0.54^{b}$ & $77.83 \pm 0.35^{\mathrm{a}}$ & $77.05 \pm 0.48^{b}$ & $77.81 \pm 0.53^{\mathrm{a}}$ \\
\hline $\mathrm{a}$ & $0.35 \pm 0.25^{\mathrm{a}}$ & $-0.26 \pm 0.16^{\mathrm{c}}$ & $0.37 \pm 0.18^{\mathrm{a}}$ & $0.17 \pm 0.15^{\mathrm{b}}$ \\
\hline $\mathrm{b}$ & $28.86 \pm 0.83^{\mathrm{a}}$ & $27.35 \pm 0.53^{\mathrm{c}}$ & $28.43 \pm 0.47^{\mathrm{ab}}$ & $27.95 \pm 0.31^{\mathrm{b}}$ \\
\hline
\end{tabular}

${ }^{1)} \mathrm{Mean} \pm \mathrm{SD}(\mathrm{n}=5-10)$.

${ }^{2) a-d}$ Means with different superscript are significantly different by Duncan's multiple test $(p<0.05)$. 

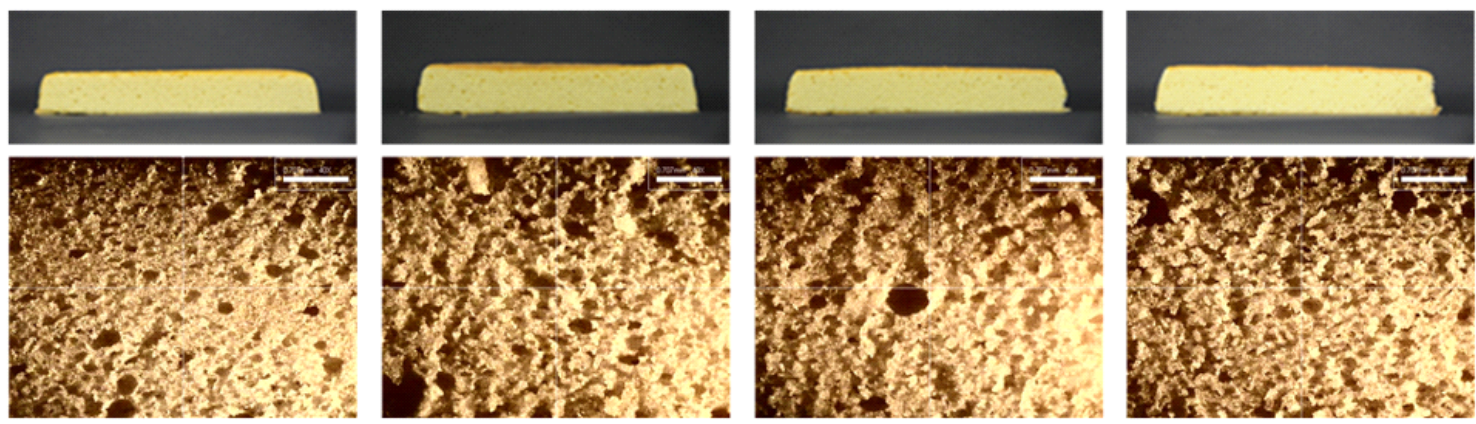

Suwon 542

Ilmi

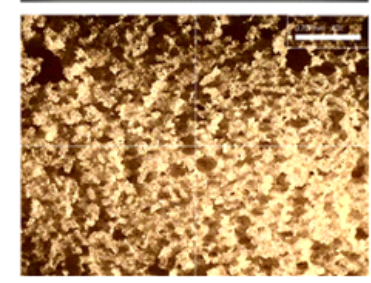

Goami

Fig. 1. Cross section shape (up) and crumb structure (down) of sponge cake prepared with different rice flours.

Table 4. Texture of sponge cake prepared with different rice flours

\begin{tabular}{cllll}
\hline Sample & 'Suwon 541' & 'Suwon 542' & 'Ilmi' & 'Goami' \\
\hline Hardness (kg) & $0.76 \pm 0.08^{1) \mathrm{a} 2)}$ & $0.46 \pm 0.03^{\mathrm{c}}$ & $0.57 \pm 0.02^{\mathrm{b}}$ & $0.58 \pm 0.04^{\mathrm{b}}$ \\
Springiness & $0.90 \pm 0.02$ & $0.91 \pm 0.01$ & $0.90 \pm 0.01$ & $0.91 \pm 0.02$ \\
Cohesiveness & $0.54 \pm 0.01$ & $0.56 \pm 0.02$ & $0.54 \pm 0.03$ & $0.55 \pm 0.01$ \\
Chewiness & $0.37 \pm 0.04^{\mathrm{a}}$ & $0.23 \pm 0.01^{\mathrm{c}}$ & $0.28 \pm 0.02^{\mathrm{b}}$ & $0.29 \pm 0.02^{\mathrm{b}}$ \\
\hline
\end{tabular}

${ }^{1)} \mathrm{Mean} \pm \mathrm{SD}(\mathrm{n}=6)$.

${ }^{2) a-c}$ Means with different superscript are significantly different by Duncan's multiple test $(\mathrm{p}<0.05)$.

Table 5. Sensory evaluation of sponge cake prepared with different rice flours

\begin{tabular}{ccccc}
\hline Sample & 'Suwon 541' & 'Suwon 542' & 'Ilmi' & 'Goami' \\
\hline Color & $4.82 \pm 1.09^{1)}$ & $4.97 \pm 1.17$ & $4.91 \pm 0.93$ & $4.68 \pm 1.07$ \\
Flavor & $4.79 \pm 1.32^{\mathrm{ab} 2)}$ & $4.29 \pm 0.94^{\mathrm{bc}}$ & $4.88 \pm 0.95^{\mathrm{a}}$ & $4.15 \pm 0.96^{\mathrm{c}}$ \\
Taste & $4.88 \pm 1.30$ & $5.18 \pm 1.11$ & $5.15 \pm 1.21$ & $5.09 \pm 1.22$ \\
Texture & $3.26 \pm 1.11^{\mathrm{c}}$ & $5.74 \pm 1.08^{\mathrm{a}}$ & $5.06 \pm 1.18^{\mathrm{b}}$ & $4.53 \pm 1.19^{\mathrm{b}}$ \\
Overall acceptability & $3.50 \pm 0.90^{\mathrm{c}}$ & $5.24 \pm 1.05^{\mathrm{a}}$ & $5.09 \pm 1.26^{\mathrm{a}}$ & $4.38 \pm 1.41^{\mathrm{b}}$ \\
\hline
\end{tabular}

${ }^{1)} \mathrm{Mean} \pm \mathrm{SD}(\mathrm{n}=34)$.

2)a-c Means with different superscript are significantly different by Duncan's multiple test $(\mathrm{p}<0.05)$.

와 비용적이 가장 컸기 때문으로 생각된다(Table 5). 케이크 의 물성은 수분함량, 기공의 발달 정도, 케이크의 부피와 같 은 여러 요인의 영향을 받는다(Majzoobi 등, 2016).

\section{스펀지케이크의 관능특성}

쌀품종에 따른 스펀지케이크의 기호도를 측정한 결과는 향미, 질감 및 전체적인 기호도에서만 품종간에 차이를 보였 다(Table 5). 비용적이 가장 높게 나타난 수원 542에서 질감 에 대한 기호도가 높았다. 전체적인 기호도는 수원 542와 일 미에서 각각 5.24 및 5.09로 높았고, 수원 541에서 3.50으로 가장 낮은 기호도를 보여 케이크의 기호도는 질감에 큰 영향
을 받는 것으로 생각된다. 기호도검사 결과에서 쌀 품종은 스 펀지케이크의 색과 맛에 대한 기호도에는 영향을 주지 않았 으나, 향미, 질감 및 전체적인 기호도에서는 품종 간 차이를 보였고, 수원 542와 일미 쌀가루를 이용한 스펀지케이크가 관능적으로 우수하게 평가되었다.

\section{요 약}

본 연구에서는 수원 541, 수원 542, 일미 및 고아미 쌀품종 이 스펀지케이크의 가공적성에 미치는 영향을 알아보기 위하 여 쌀가루의 이화학적 특성을 비교하고, 품종별 쌀가루를 이 
용한 스펀지케이크의 품질 특성을 분석하였다. 국내에서 가 공용으로 생산되는 4품종의 쌀가루는 이화학적 특성, 호화특 성, 반죽 및 스펀지케이크 특성에서 차이를 보였다. 아밀로오 스 함량은 고아미에서 가장 높았고, 평균 입자크기는 수원 542에서 $21.87 \mu \mathrm{m}$ 로 유의적으로 낮았다. WAI는 고아미에서 높았고, WSI는 수원 541에서 높았다. 아밀로그램 호화특성 측정 결과, 호화개시온도는 수원 541에서 높았고, setback은 일미에서 가장 낮았다. 고아미를 이용한 스펀지케이크에서 L 값은 높았고, $\mathrm{a}$ 값과 $\mathrm{b}$ 값은 유의적으로 낮았다. 수원 542 를 이 용한 스펀지케이크의 비용적은 유의적으로 높았고, 경도와 씹힘성은 낮은 경향을 보였다. 수원 541 쌀가루는 높은 호화 개시온도에 의해 낮은 케이크 부피와 높은 경도를 보였다. 수 원 542 쌀가루는 낮은 아밀로스 함량, 미세한 입자크기, 낮은 WAI와 WSI를 나타냈고, 반죽의 낮은 비중, 높은 케이크 부 피로 인해 낮은 케이크 경도를 보였으며, 기호도 또한 높았 다. 일미 쌀가루는 낮은 setback으로 케이크의 노화지연 효과 가 있을 것으로 예상되며, 스펀지케이크의 기호도가 높았다. 아밀로스 함량이 높은 고아미 쌀가루는 큰 입자크기, 밝은 색 상, 높은 $\mathrm{WSI}$ 를 보였다. 고아미 쌀가루로 제조한 스펀지케이 크의 특성은 양호하였으나, 높은 setback은 빠른 노화로 인한 질감의 저하가 예상되었다. 관능검사 결과에서 전체적인 기 호도는 수원 542와 일미에서 높았다. 본 실험을 통해 스펀지 케이크의 제조 시 수원 542와 일미 품종의 가공적성이 우수 한 것으로 확인되었다.

\section{Conflict of interests}

The authors declare no potential conflict of interest.

\section{ORCID}

Hee Nam Jung https://orcid.org/0000-0003-4236-5641

\section{References}

AACC. Approved Methods of the AACC. 10th ed, AACC International, St Paul, MN, USA (2000)

Abebe W, Collar C, Ronda F. Impact of variety type and particle size distribution on starch enzymatic hydrolysis and functional properties of tef flours. Carbohydr Polym, 115, 260-268 (2015)

An HK, Cho SG, Hong GJ. The characteristics of sponge cake added with Suaeda asparagoides. Culi Sci Hos Res, 22, 1-10 (2016)
Capriles VD, Areas JAG. Novel approaches in gluten-free breadmaking: Interface between food science, nutrition, and health. Compr Rev Food Sci Food Saf, 13, 871-890 (2014)

Chaiwanichsiri S, Thumrongchote D, Suzuki T, Laohasongkram K. Properties of non-glutinous thai rice flour: Effect of rice variety. Res J Pharm Biol Chem Sci, 3, 150-164 (2012)

Chiang PY, Yeh AI. Effect of soaking on wet-milling of rice. J Cereal Sci, 35, 85-94 (2002)

Choi SY, Lee SH, Lee YT. Properties-of rice flours prepared from milled and broken rice produced by pre-washing process. J Korean Soc Food Sci Nutr, 34, 1098-1102 (2005)

Edoura-Gaena RB, Allais I, Trystram G, Gros JB. Influence of aeration conditions on physical and sensory properties of aerated cake batter and biscuits. J Food Eng, 79, 1020-1032 (2007)

Gujral HS, Mehta S, Samra IS, Goyal P. Effect of wheat bran, coarse wheat flour, and rice flour on the instrumental texture of cookies. Int J Food Prop, 6, 329-340 (2003)

Han JA. Development and characterization of rice cookies containing germinated yakkong powder. Korean J Food Cookery Sci, 27, 681-689 (2011)

Heo IH, Lee SH. Wheat import of south Korea and climate variation: In the case of the United States. J Climate Res, 10, 219-230 (2015)

Huh CK, Shim KH, Kim YD. Comparison of physicochemical properties between conventional and high-yielding rice varieties. Korean J Food Sci Technol, 48, 20-26 (2016)

Kang TY, Jo HE, Sohn KH, Yoon MR, Lee JS, Lee SY, Ko SH. Effect of rice variety on the processability for preparing rice cookies. Korean J Food Sci Technol, 48, 492-495 (2016)

Kim HJ, Park JY, Lee SK, Park HY, Cho DH, Choi HS, Oh SK. Quality characteristics of rice cultivars suitable for rice beer. Korean J Crop Sci, 62, 113-117 (2017)

Kim MK, Lee EJ, Kim KH. Effects of Helianthus tuberosus powder on the quality characteristics and antioxidant activity of rice sponge cakes. Korean J Food Culture, 29, 195-204 (2014)

Kim MR. The status of Korea's rice industry and the rice processing industry. Food Indistry and Nutrition, 16, 
22-26 (2011)

Kim MS, Park JD, Lee HY, Kum JS. Effect of rice flour prepared with enzyme treatment on quality characteristics of rice cookies. J Korean Soc Food Sci Nutr, 42, 1439-1445 (2013)

Kim SS, Chung HY. Effects of the type and percentage of a lipid on the quality characteristics of rice bread depending on the use of wet and dry rice flour. Korean J Food Nutr, 31, 511-519 (2018)

Kim RY, Park JH, Kim CS. Effects of enzyme treatment in steeping process on physicochemical properties of wetmilled rice flour. J Korean Soc Food Sci Nutr, 40, 1300-1306 (2011)

Kringel DH, Filipini GS, Salas-Mellado MM. Influence of phosphorylated rice flour on the quality of gluten-free bread. Int J Food Sci Technol, 52, 1291-1298 (2017)

Krupa-Kozak U, Drabinska N, Rosell CM, Fadda C, Anders A, Jelinski T, Ostaszyk A. Broccoli leaf powder as an attractive by-product ingredient: Effect on batter behaviour, technological properties and sensory quality of gluten-free mini sponge cake. Int J Food Sci Technol, 54, 1121-1129 (2019)

Lee MJ, Hwang ES. Quality characteristics and antioxidant activity of rice sponge cake with added green tea powder. Korean J Food Sci Technol, 48, 354-360 (2016)

Lee MK, Shin MS. Characteristics of rice flours prepared by moisture-heat treatment. Korean J Food Cookery Sci, 22, 147-157 (2006)

Lee S, Lee EJ, Chung HJ. Structural and physicochemical characterization of starch from Korean rice cultivars for special uses. Korean J Food Sci Technol, 49, 1-7 (2017)

Lee SY. Quality characteristics of rice flour sponge cakes containing various levels of pumpkin powder. MS Thesis, Hansung University, Korea, p 15-80 (2010)

Majzoobi M, Poor ZV, Jamalian J, Farahnaky A. Improvement of the quality of gluten free sponge cake using different levels and particle sizes of carrot pomace powder. Int J Food Sci Technol, 51, 1369-1377 (2016)

Oh HA, Kim MY, Lee YJ, Song MS, Lee CK, Lee YR, Lee JS, Jeong HS. Quality characteristics of rice bread with different cultivars and milling methods. Korean J Food Sci Technol, 50, 492-498 (2018)

Oh SK, Kim DJ, Ryu SJ, Chun A, Yoon MR, Choi IS, Hong HC, Kim YK. Quality characteristics of Korean traditional wine using Seolgaengbyeo for brewing rice. J Korean Soc Food Sci Nut. 40, 1189-1194 (2011)

Park JY, Lee SK, Park HY, Choi HS, Cho DH, Lee KH, Han SI, Cho JH, Oh SK. Physicochemical properties of rice flour of different cultivars using wet and dry milling processes. Korean J Crop Sci, 62, 184-192 (2017)

Seo HI, Kim CS. Pasting properties and gel strength of non-waxy rice flours prepared by heat-moisture treatment. J Korean Soc Food Sci Nutr, 40, 196-204 (2011)

Sompong R, Siebenhandl-Ehn S, Berghofer E, Schoenlechner R. Extrusion cooking properties of white and coloured rice varieties with different amylose content. Starch/Stärke, 63, 55-63 (2011)

Wadchararat $\mathrm{C}$, Thongngam M, Naivikul O. Characterization of pregelatinized and heat moisture treated rice flours. Kasetsart J Nat Sci, 40, 144-153 (2006)

Williams PC, Kuzina FD, Hlynka I. A rapid colorimetric procedure for estimating the amylose content of starches and flours. Cereal Chemistry, 47, 411-420 (1970)

Wronkowska M, Haros M, Soral-Smietana M. Effect of starch substitution by buckwheat flour on gluten-free bread quality. Food Bioprocess Technol, 6, 1820-1827 (2013)

Yoon MR, Chun AR, Oh SK, Ko SH, Kim DJ, Hong HC, Choi IS, Lee JH. Physicochemical properties of endosperm starch and breadmaking quality of rice cultivars. Korean J Crop Sci, 56, 219-225 (2011) 